\title{
Research Paper An study of factors which abstain consumers from
online shopping in Kanpur city of Uttar Pradesh
}

\author{
Rini Charan and Suprit John Joshi
}

See end of the paper for authors' affiliations

Correspondence to :

\section{Rini Charan}

Joseph Institute of Business Studies, Sam Higginbottom University of Agriculture, Technology and Sciences, Allahabad (U.P.) India Email : rini.charan@ gmail.com

\section{Paper History :}

Received : 14.07.2018;

Revised : 03.08.2018;

Accepted : 06.09.2018
ABSTRACT : E-commerce has made it easier for small business owners, artists and entrepreneurs to sell online from an online store or website. It is easy for the customers to compare products online than at malls or physical stores and there is a lot of information available online regarding products so why not use this vast information. This study will help the e-tailers to change their course of action, logistics or marketing strategies to attract more customers online and win their trust with lesser complains and increased profit for the firm. Samples were selected by convenient and purposeful sampling from a large number of customers at Kanpur. The sample size was 118 and people were interviewed from various areas of Kanpur to get diversity in the sample. The data was analysed by using percentage method. Out of 118 respondents 22 face the problem of not getting products delivered at their door step which represents 19 per cent of respondents. 68 per cent respondents find high prices of a product (when compared to the price of the same product offline) a major reason to abstain them from purchasing online. There has been a number (30 out of 118 respondents) of respondents who have experienced a change in colour of the actual product yet that number counts and because of this these respondents do not want to shop online with those particular websites and lose their trust on most shopping sites. Out of 118 respondents 103 have received poor or low quality of products which did not match to their expectation and so they now do not want to continue shopping online with particular websites because of such products received through online purchase. This number shows 87 per cent (a major portion) of respondents who have already lost their trust on various e-tailers. Around 64 per cent respondents abstain from shopping online as they do not want to disclose their account number or debit/credit card details to websites which cannot be trusted for personal details and do not provide COD facility.

KEY WORDS : Online shopping, Respondents, Purchase

HOW TO CITE THIS PAPER : Charan, Rini and Joshi, Suprit John (2018). An study of factors which abstain consumers from online shopping in Kanpur city of Uttar Pradesh. Res.J. Agric. Eco. \& Stat., 9 (2) : 373-377, DOI : 10.15740/HAS/IRJAES/9.2/373-377. Copyright@ 2018: Hind Agri-Horticultural Society. 